\title{
Are Fruits of Free Normal Education Policy Real or Mythical? \\ A Critical Appraisal of the Free Teacher Education Policy Meant to Promote Rural Education in China
}

\author{
Zubing Luo ${ }^{1}$, Matthews Tiwaone Mkandawire ${ }^{1}$ \\ ${ }^{1}$ School of Education, Central China Normal University, Wuhan, China \\ Correspondence: Zubing Luo, School of Education, Central China Normal University, LuoYu Road No.152, Wuhan \\ 430079, Hubei Province, China
}

Received: January 13, 2015

Accepted: February 6, 2015 Online Published: March 16, 2015

doi:10.11114/jets.v3i3.722

URL: http://dx.doi.org/10.11114/jets.v3i3.722

\begin{abstract}
Since September 2007, the Ministry of Education of China has been implementing a policy called 'Free Normal Education' (FNE) for college students majoring in education in normal universities. The central goal for FNE is to promote quality of education by providing rural areas with high quality teachers who are bonded through their tuitionfree training. This study analysis has shown that after more than five years of implementation, it is unfortunately evident that FNE may not achieve its key objective of improving rural education. There are many reasons attributed to this drawback. But the most serious one is that the government only emphasizes on providing teachers in rural areas without caring about the general welfare and salary motivations that the rural teachers would get. Further, there are no clear structures to ensure that students trained through the FNE policy would necessarily stay in rural areas. This paper, therefore, recommends that multiple measures, with a holistic view, should be taken so that the policy is supported to achieve its intended goal.
\end{abstract}

Keywords: free normal education, normal universities, rural education, substitute teachers

\section{Introduction}

This paper is a critique about the introduction and implementation of the Free Normal Education (FNE) policy in China. The FNE policy was introduced in September 2007 with the general aim of promoting the quality of education in China through training and provision of good quality teachers for the rural areas. Ironically, many studies show that the policy is facing serious challenges such that rural education in China is still lagging behind ( $\mathrm{Li}, 2010$, Zhou, 2010, Cao, 2012). This paper therefore presents an analytical study of the above policy with reference to its intended goals. In terms of format, this paper starts by (a) spelling out background information about FNE; (b) it outlines strengths of the policy; (c) then scrutinizes challenges faced by the policy and; (d) ends by suggesting ways that would help achieve purposes of the policy which are generally to promote quality of education in rural China.

\section{Purpose and Methodology of the Study}

The main aim of this study was to assess the strengths and limitations of the FNE policy in its drive to achieving its core objective of ensuring quality of education in rural areas and China, as a whole. Specifically, the study used the qualitative methodology in its approach and utilized secondary data to affirm that the key intended purpose of this policy was to promote quality of education in rural areas. Using a critical analysis framework, secondary data were also used to appraise the context under which the policy was formulated and implemented to unearth its strengths and limitations. Finally, based on the appraisal, the study sought to raise critical suggestions that could help pragmatically promote education in rural and other disadvantaged areas of China.

\section{Background of Free Normal Education in China}

From 2007, the Ministry of Education of China has been implementing a policy which is called "Free Normal Education" for college students majoring in education in six main normal universities affiliated to the Ministry of Education. This means that from that year on, the students majoring in education in Beijing Normal University, East China Normal University, Central China Normal University, Shanxi Normal University, Southwest University, and 
Northeast Normal University are exempted from tuition fees which the government pays instead. Further, these students get living expenses during university study from the government.

However, Free Normal Education (otherwise also called free teacher education) is not generally a new education policy. As a matter of fact, it is just a recurrence of free teacher education that had been there before. This is because, since 1949 when People's Republic of China was founded, all universities in China had been free for every undergraduate and graduate; and so normal universities were no exceptions. However, many universities in China started to charge tuition fees from 1989 under the influence of market economy reform which introduced a market approach into higher education (Fan, 2005). By the year 1997, all universities in China were beginning to ask their students to pay tuition fees. Prior to this market-based reform, tuition fees for university students were provided by the state, and as a result, after graduation graduates' jobs were entirely arranged by the government. So graduates had no choice about where they would work and what job they would get. But after 1997, university graduates were now able to choose their jobs freely. Under these circumstances, when graduates were looking for a job, they would think about whether the salaries of the job they would get are compatible with the expenses they made for their education. Generally speaking, most universities graduates were from that time unwilling to work in less developed areas or rural areas because of the poor economic condition. According to a research, "from 2006 to 2010, there were about $80 \%$ of the graduates who worked in big and middle cities"; the rest worked in small cities and rural areas (Yue, 2012). As a result, serious problems occurred as about no graduates were coming to work in rural areas. This implied that the quantity and quality of teachers in rural schools were not updated at least in the past 10 years. To make matters worse, a great number of outstanding teachers originally working in rural areas came to cities in pursuit of better salaries. It is stated in National Report of Education Inspection 2008 (Summary) (NREI 2008) that "a sample survey of schools in poverty areas showed that $38.7 \%$ of principals said that there existed teachers leaving their school in the past three years, and of which, $74.6 \%$ of principals indicate that teachers who left schools were mainly experienced and reliable teachers. And $92.5 \%$ of principals mentioned that the age of teachers who left rural schools were mostly younger than 35-year-old"(Ministry of Education [ME], 2008). This situation has severely impeded the development of education in rural areas in China.

Nevertheless, it is well understood that development of rural education in China can have far-reaching influences on the whole education and development of the country in general. In a deeper sense, it would have great impacts on the whole country's economic development and overall national strength. According to the Communique of National Bureau of Statistics of the People's Republic of China on Major Figures of the 2010 Population Census(No.1), in China, "665 575 306 people were urban residents, accounting for 49.68\%; and 674149546 persons were rural residents, making up 50.32\%" (National Bureau of Statistics of China, 2011). This indicates that more than a half of China will lag behind in education if the rural education does not get better. But for a long time, the quality of education in rural areas has been far lower than that in cities, which can be seen through the lens of high school education, where the number of students in rural areas is smaller than that in cities. According to statistics (Department of Development \& Planning Ministry of Education, 2010), in 2010, the number of high school students in cities was 8582032 , and newly recruited students were 2930 927; the number of high school students in towns was 14062 284, and new students were 864 291; and the number of high school students in rural areas was 1629 035, while fresh students were 567141 (pp.305-307). On the other hand, there is a fairly small proportion of high school students in rural areas getting the opportunities to study in universities. For instance, "In recent years, only about $15 \%$ of students in rural areas were admitted to Peking University and Tsinghua University which are considered the most prestigious universities in China. University students coming from rural areas in Zhejiang University, Nanjing University, and Chinese Agricultural University account for $30 \% "$ (Cao, 2012). Research has also shown that "the opportunity of studying in university for city high school students is 6.3 times that of rural high school students." (Li, C. L., 2010)

There are many factors contributing to the problems described above, but the most serious one is lack of high quality teachers in rural areas. Data in NREI 2008 show that elementary and middle schools in China still had more than 379 000 substitute teachers, among whom 272000 were in elementary schools, and over $87.8 \%$ of them were working in rural areas. In Guangdong Province, Guangxi Province and Gansu Province, substitute teachers accounted for the largest proportion of teachers in China, exceeding $10 \%$ of the staff in elementary schools. In terms of the more developed province of Fujian Province, there were 344919 teachers in elementary and secondary schools in total, including 311405 full-time teachers and 33514 substitute teachers, accounting for $90.28 \%$ and $9.72 \%$ separately. A study by Zhou shows that the percentages of teachers who have required academic degree in elementary school, middle school and high school are $99.05 \%, 97.94 \%$ and $84.13 \%$ respectively. And the proportion of teachers with associate degree reaches $56.09 \%$ in elementary school; teachers in middle school with bachelor's degree are $46.17 \%$. However, the degree-standard-reaching rates of teachers in rural elementary school, middle school, high school are $98.67 \%$, $97.56 \%$ and $78.985 \%$ separately, of which the proportion of teachers with associate degree in rural elementary schools gets to $47.59 \%, 37.38 \%$ of teachers with a bachelor's degree in rural middle schools. The proportion of full-time 
teachers with senior professional titles accounts for only $0.337 \%$ in elementary schools, $8.20 \%$ in middle schools and $19.66 \%$ in high schools in rural areas (Zhou, 2010). The quality of teachers of other under-developing provinces and regions should be even worse than this. These statistics show clearly that education standards in rural areas are pathetically lagging behind.

In the context of the aforesaid situation, Premier Wen Jiabao delivered a report on the work of the government in March 5, 2007 and stated clearly that "we will implement Free Normal Education for college students majoring in education in normal universities affiliated with Ministry of Education and establish a corresponding system."(Wen, 2007) By now, FNE has been operating for more than seven years. And the first two cohorts of free normal graduates already went into work. It can be confidently concluded that one of the missions of FNE is to improve education of rural areas. However, is it achieving its original aim of enhancing education of countryside of China? Are there any serious challenges emerging during implementation of FNE policy? These issues are critically discussed in this paper.

\section{Improving Rural Education: Great Mission of Free Normal Education}

Rural education is the "short plank" of education in China. China has a population of more than 1.3 billion, over half of them living in rural areas. And therefore the reform and development of rural education will have a direct impact on the quality of education of the country as a whole, and directly relate to the goals of China to build a well-off society and to realize modernization. Currently, great emphasis has been put on improving the facilities and the teaching environment in rural areas. Meanwhile, varieties of policies aiming at enhancing the quality of teachers in rural areas have gradually been put on the agenda. It is safe to say that one of the important measures came out in May of 2007 when the General Office of the State Council released the Notice of the Measures for Implementing Free Normal Education at Normal Universities Affiliated with Ministry of Education' (for Trial Implementation) which marked the beginning of FNE. The notice does not say directly that improving rural education is the aim of FNE, but we can figure it out from different aspects that improving education in rural areas of China is the most important concern of the policy of FNE.

\subsection{To Improve Rural Education through FNE is one of the Statesman's Expectations}

In a sense, it can be said that Wen Jiabao, the Premier of China, initiated the FNE. Wen Jiabao held 4 forums about education from July to November in 2006 for the preparation of the policy of FNE and said that the development of China depends on the quality of education which is determined by the quality of teachers. He also noted that a large quantity of high quality teachers is still needed urgently in China. In one of the Forums, Wen Jiabao pointed out that "we should take measures to improve teachers' comprehensive quality and treatment in rural schools, to protect the legitimate rights of the teachers, and to make sure that the traditional virtues of respecting teachers and cherishing students prevail in urban and rural areas of the country" (Xinhua Net, 2006). It was not long after the forums that the policy of FNE was enacted. It is hence certain that the policy would like to achieve multiple goals, but the most important one is to improve the quality of rural education. This can be deciphered from Wen Jiabao's series speech. In 2010, Wen Jiabao, having conversations with teachers at Liudaohe Middle School of Xinglong County, Hebei province on Teachers' Day of 2010, clarified the background of the policy of FNE from the perspective of unequal access to education between urban and rural students. He said, "If we do not run rural schools very well, the conditions of education for children in rural areas will be far behind their counterparts in urban areas. Based on this, an experiment to provide FNE at normal universities affiliated with Ministry of Education was conducted by the State Council in 2007." In the last section of the conversation, Wen Jiabao expressed high expectations to tuition-free normal university students to improve the quality of rural education. He said, "Today, the forum was attended by representatives of university students receiving FNE from Beijing Normal University, who are the newborn force of rural teachers in the future and the key to improving the quality of rural education" (Wen, 2011a). A year later, Premier Wen Jiabao made a clear statement again about the orientation on the policy of free teacher education in his speech on the Rural Teachers Conference in Zhangbei County of Hebei Province when he said, "we will manage to perfect Free Normal Education, and strengthen the guiding function of the policy further, to focus on cultivating large numbers of model teachers for rural schools and support tuition-free normal graduates to take up teaching jobs and accelerate their professional growth and long-term development" (Wen, 2011b). On June $17^{\text {th }}$ of 2011, Premier Wen Jiabao said at the graduation ceremony of the first cohort of tuition-free normal graduates at Beijing Normal University, "a few years ago, most of excellent students didn't want to be a teacher, even normal university students were not willing to become teachers, and they were more reluctant to work in the elementary and secondary schools in central and western regions. I was concerned about this awfully" (Wen, 2011c). In a series of speeches, Wen Jiabao expressed the expectations for tuition-free normal graduates to teach in rural areas. It is thus clear that the leader expects the quality of education in rural areas to be boosted through the policy of FNE.

\subsection{To Improve Education in Rural Areas is the Original Intention of the Policy of FNE}

The Notice of Measures for Implementing Free Normal Education at Normal Universities Affiliated with Ministry of 


\section{Education (for Trial Implementation) stipulates that:}

"tuition-free normal university students need to sign agreements with universities and education administrative departments of the province where they were born before enrollment with normal universities and promise that they would engage in teaching in elementary and secondary schools more than a decade after graduation. Tuition-free normal graduates must teach in rural schools for two years first if they want to take up teaching jobs in cities." (General Office of the State Council [GOSC], 2007a)

In the notice not only does it require clearly that tuition-free normal graduates should teach in rural schools, but also stipulate that "local government and rural schools should provide necessary working and living conditions and temporary housing for graduates to ensure that they can make contributions successfully in rural areas"( GOSC, 2007a). In addition, another document entitled Measures for Placement of Employment of Free Normal Graduates Studied in Normal Universities Affiliated with Ministry of Education was released in May, 2010, and it says "government should encourage the graduates to teach in remote and impoverished areas and ethnic areas" (ME et al, 2010). It puts forward more detailed and more flexible policies for the graduates to serve for rural education. For instance, it even includes benefits that tuition-free normal graduates can get after going to rural areas. "Tuition-free normal graduates who plan to take up teaching jobs in cities are arranged to serve education in rural areas for two years by the local education administrative departments, and they still enjoy the same salaries and benefits as the city teachers' during teaching service for rural schools" (ME et al, 2010). Obviously, the original intention of the series of policies launched by state was to support and improve the quality of rural education by ensuring that tuition-free normal graduates comply with their duties to serve in rural areas for at least two years.

\subsection{To Improve Education in Rural Areas via FNE is the Concerns of Scholars}

Soon after the FNE was launched, many researchers made analyses of the new policy. Lots of analyses point out directly that one of the tasks of the policy is to optimize teaching force in rural areas, and improve the quality of rural education. Some scholars believe that FNE was conducive to improve rural education and realize educational equity. For instance, Fu and Yang conclude that "The purpose of these measures is to encourage and guide students graduated from normal universities to teach for a long time and even for a lifelong time, encourage and support them to take up teaching jobs in rural schools to facilitate the development of the national basic education ultimately, especially support the basic education in rural and poor remote areas, and promote educational equity by the intervention of the policies" (Fu \&Yang, 2012). Other researchers think that free teacher education can be instrumental to enhancing the quality of teachers in rural areas. In this vein, Dong says "this means that the state ensures the stable sources of outstanding teachers for rural primary and secondary schools from the institutional level in order to effectively improve the quality of teachers in rural areas" (Dong, 2007). And still other researchers discussed FNE from the perspective of promoting equity in education and constructing a harmonious society, maintaining that "the policy highlights the reality that the rural areas are short of high-quality teachers seriously"(Liu \& Dang, 2007). And it is also important to achieve equitable development of education and train a large number of highly qualified teachers for mid-west rural areas, to solve the problem of insufficient high-quality teachers in rural areas, to narrow the gap between urban and rural education and to lay a solid foundation for building a harmonious society" (Liu \& Dang, 2007). From the above scholar's analyses, it is indicative that the FNE policy has the potential to raise the standards of education in China with focus on rural and other disadvantaged areas.

\section{Challenges facing Free Normal Education to Promote Rural Education}

FNE is facing many difficulties in its thrust to promoting rural education in China. This section describes and discusses some of the precarious challenges that FNE policy faces in attempts to promote rural education.

\subsection{There are no Supporting Measures for Graduates to Work in Rural Areas}

From the outset, it should be noted that helping graduates to be willing to work in rural areas ought to be a systematic approach that requires support from all stakeholders. This is because there exist many obstacles for graduates to work well in rural areas. First of all, there is lack of supporting policy for FNE graduates to work in rural areas. Although it is clearly stipulated by GOSC (2007a) that graduates should be engaged in teaching at least ten years after graduation and during which they must teach in rural schools for at least two years, there is no detailed policy to ensure this. For example, the policy does not say exactly at what time graduates should go to fulfill the obligations; and it does not state how to evaluate the work done by graduates during the time they are working in rural areas. While that silence in policy may have meant to give flexibilities to each province and city, unfortunately it creates the possibility that the graduates in some provinces may not immediately work in countryside. For example, the director Yue Cong'ge in Yuxi No.1 High School said, "as one of the best high schools in Yunnan province, teachers in Yuxi No.1 High School are still very inadequate despite the coming of free-normal-education graduates, so it is impossible for us to let them work in rural areas" (Tian, 2011). In this way, the purpose of the FNE policy to support education in rural areas will eventually vanish 
into thin air. Secondly, there are no substantial incentives to FNE graduated teachers so that they can stay in rural areas which are less advantaged socio-economically. Over the years, the main reason why less and less outstanding teachers are willing to work in rural schools is the poor working and living conditions in rural areas and that the prospects of career development for rural teacher is not optimistic, coupled with the meager income and low social status. Under such a scenario, to improve rural teachers' welfare is the only way to motivate enthusiasm of free-normal-education graduates to serve for rural education. In addition to provision of incentives, the policy could allow that working in rural areas be made part of graduates' own choice. Otherwise, lack of incentive will not help the FNE policy to make high-quality graduates work in undeveloped areas and promote the quality of education.

\subsection{The Policy of Supporting Rural Education Itself is Unable to Improve Rural Education}

It is said in the document of Notice of Measures for Implementing Free Normal Education at Normal Universities Affiliated with Ministry of Education (for Trial Implementation) that "tuition-free normal graduates should support rural education for two years under the arrangements of local administrative departments of education if they want to take up teaching jobs in cities" (GOSC, 2007b). Supporting rural education for two years is a special policy in China which means that graduates can find their job in cities after two years' service in rural areas. If they go to support rural education for only two years, the tuition-free graduates would unfortunately not play significant roles in the improvement of rural education. There are several reasons for this argument. Firstly, the obligations to support rural education just for two years are generally performed in the first two years after students' graduation. During the first two-year period, graduates may not get solid basic skills of education and may not have fundamental working experiences gained in city schools where they do their internship for a period of three months which is not enough to develop sound teaching ability. In fact, in the first period of teaching, graduates are likely to face mismatch conflicts between teaching in cities, where they did their internship, and teaching in rural areas. Therefore, most of them would not have the abilities to improve the quality of rural education. Secondly, during this period, most free-education students do not have their own understanding and views on education. Hence, when they go into work, they are not likely to play a leading role in improving rural education. Rather, they are likely to be assimilated by the style and habits of rural teachers when they go to the countryside to support education. Consequently, they may lose the courage and ability to reform education thereby becoming just like the typical rural teachers themselves. Thirdly, because free-education graduates are likely to leave the rural schools after the expiration of the two-year work, the turnover and instability will cause serious interference and disturbance for rural education and ultimately lead to the fact that "rural schools will only become the internships base for training outstanding teachers for city schools"(Wang, 2011). Fourthly, the stipulation of supporting education for two years leads to free-education graduates considering it an obligation to meet in rural schools, not an undertaking that they should pursue. They will be thinking of how to leave quickly once they go to the countryside. This could result in loss of focus on their path to professional development by messing around for two years.

\subsection{Free Normal Education does not guarantee provision of quality teachers for rural schools}

Although the policy of FNE does not explicitly stipulate that normal universities only can recruit rural high school students, practically rural students and the midwest (poverty zone) students account for the vast majority during actual enrollment. Meanwhile, because the FNE policy requires working in rural areas for obligations where the welfare of teachers is not attractive, city high schools' students are unwilling to attend free teacher education. "In 2007, the most of matriculation quotas of normal universities affiliated with Ministry of Education were mainly given to midwest areas which account for 90.8\%" (Jiang, 2007). In a sense, it can be said that the policy of exemption from tuition fees of normal university students has indirectly become an anti-poverty project that is giving support to the rural students to help them finish university education and help them get employment. If this is the case, then ironically government "considers teacher education as no more than an instrument to achieve another policy goal, which they did not take the time to carefully consider either the feasibility or implications of their recommendations" (Early, 2008). Therefore, it can be argued that this policy does not promote rural education in the end. First of all, since most graduates who come from countryside will go back to teach in the countryside after their graduation, this will lead to the realization that their simple and reasonable dream to change their own fate by college education has being dashed to the ground. As a result, they would inevitably have a sense of loss. To some extent, it has a negative effect on the enthusiasm of rural children to study hard and work in cities. Secondly, rural children do not only need teachers growing up in rural areas to teach them but also teachers coming from cities. Only with "able, diverse, and committed" teachers in rural areas can rural children's horizons be opened up, can they get full development (Hallinan \& Khmelkov, 2001). And yet the policy of FNE cannot guarantee this.

\subsection{Free Normal Education Itself Needs to Be Reviewed}

Although six affiliated normal universities have made great efforts on education for tuition-free normal students and 
have made a lot of creative reforms, judging from the current situation, there are still many problems in FNE.

Firstly, tuition-free undergraduates lack desires to teach in rural areas. Some scholars conducted a survey on students enrolled in 2007 of East China Normal University and the results show that "only 27.54\% of tuition-free normal students were willing to teach in rural areas. On a sharp contrary, there were $50.24 \%$ of the students unwilling to teach in rural areas." (Liu, Xie, Li \& Liu, 2009) Another research conducted by the Central China Normal University on the employment intentions of the first batch of tuition-free students graduated from six affiliated normal universities showed that "up to $90 \%$ of graduates were willing to take up teaching jobs in medium and small cities or big cities. On the other hand, only $2 \%$ chose to teach in rural places" (Gan, 2011). We can therefore see that free normal students have the low enthusiasm and even no willingness to join the workforce for rural education. The common state of unwillingness of free normal students to teach in rural areas is directly contrary to the original intention of the NFE policy, which is designed for promoting education in rural areas.

Secondly, undergraduates are seriously short of training in teaching skills. Since the implementation of the policy of FNE, six normal universities have implemented many reforms on university education and teaching in order to make graduates become excellent teachers. However, there is still some evidence which indicates that undergraduates lack appropriate teaching skills. In an investigation of one normal university, when asked "does the university pay great attention to the development of students' professional skills?"; the students thinking that the university "pays much attention" accounted for only $14 \%$, while $66 \%$ of students think that university "pays little attention" to it" (Gao, 2009). Although the majority of students thinks university places more emphasis on professional skills, they also say that they get few opportunities to practice teaching skills. Another survey about education in normal university shows that there is still a great deal of room for improvement of teaching skills' training. "When asked 'which teaching skill is the most urgently needed to improve', the percentage of tuition-free students choosing 'lecturing skills', 'instructional design skills', 'blackboard writing skills' accounts for respectively 38.2\%, 27.8\% and 20.2\%." (Li \& Sun, 2011) Therefore, with this serious shortage of training in teaching skills, normal university students may not obtain basic teaching ability which are sine qua non for the enhancement of quality education in rural areas.

Thirdly, graduates lack essential understanding about the situation of rural education. Although the majority of free-normal students come from the rural areas, it does not mean they understand the rural education well. We can know that from a set of data. For example, " $65 \%$ of students of a normal university come from rural areas, but only $6 \%$ of them think they know more about rural education; the students who know not so much and know less accounted for $22 \%$ and 50\% respectively" (Gao, 2009). Meanwhile, almost all the normal universities in China do not provide undergraduates with courses specifically on rural education. This situation is likely to lead into two consequences. One is that free-normal students only stay in a veneer of legend due to ignorance of rural education situation, and they may not profoundly understand the urgent reality that rural education needs them. They may even be indifferent with rural education. The other result is that this may affect their teaching skills needed in rural education if they are unclear about the specific requirements of rural education. There are many differences between rural education and urban education, and so the technical-know-how to teach in cities does not mean one can teach well in countryside. In sum, without context-specific training, it is difficult to make free-normal graduates themselves to adapt to rural education within two years. When they go to teach in rural areas, these graduates could be susceptible to "reality shock".

\subsection{Lastly, Very Few FNE Graduates Actually Go to Teach in Rural Schools}

The FNE policy has been implemented since the fall of 2007. Six normal universities accepted 10737 new students in total in 2007, 11383 new students in 2008, 12112 in 2009 (Sun, 2010). As it can be seen, the number of free normal students was ever-increasing annually. From the employment situation of the first and second batch of free-normal graduates, we find that a very small proportion of them went to rural areas to teach. In other words, the vast majority of graduates didn't take up teaching jobs in rural schools. According to a news report, there were 382 free-normal graduates who got the teaching jobs in Jiangxi Province in 2011, but only two of them were teaching in rural areas. There were 185 free-normal graduates in Anhui Province in 2011, but only 8 graduates went to rural areas (Wu et al, 2011). In another scenario, nobody went to rural schools in Shanxi, Inner Mongolia, Guizhou, Gansu, Qinghai and other provinces (Wu et al, 2011). The most important reason why free normal graduates are unwilling to work in rural areas is that the welfare of rural teacher is much worse than that in cities. In an interview, one free-normal graduate said, "I know that rural areas need excellent teachers, because I come from rural areas; but I will be willing to work in rural areas only if rural teachers can get better benefits and incentives than it is now" (Tian et al, 2011). This strongly suggests that reasonable incentives could greatly motivate graduates to teach in rural areas.

\section{Recommended Steps to Be Taken for Improving Rural Education}

Based on the analysis of challenges facing the FNE policy above, this section suggests a couple of measures that could be taken in a thrust to improve the quality of rural education in China. These suggestions are in keeping with the 
understanding that improving rural education cannot be merely determined by training and providing enough teachers but also by motivating teachers to work in rural areas. This section of the paper attempts to discuss a more holistic view and systematic approach needed in improving rural education to support the main objective of FNE policy.

\subsection{The First and Most Important Step Is to Enormously Improve Teachers' Welfare in Rural Areas}

Most tuition-free students who come from families which fall below the poverty line and in order to get the opportunity to exempt tuition fees, have to get about 30 grade points higher averagely in the University Entrance Examinations than those who do not major in education in the same-level universities. In short, these students are comparatively supposed to be more outstanding students. With the tuition fee exempted through the FNE policy, they can alleviate the financial burden of their families. In addition, they expect to find a good job to improve their living standards after they graduate from universities. Ironically, it is not so much attractive for tuition-free graduates to work in rural areas because the monthly income of rural teachers is much lower than that of urban school teachers. According to the summary statistics in National Report of Education Inspection (2008), in 2006, the average annual income of each faculty in primary schools and secondary schools (including middle schools and high schools) was17 729 yuan and 20979 Yuan respectively, and these figures mean 5198 Yuan and 1948 Yuan lower than those of other employees working for governments ${ }^{1}$. To make matters worse, the income gap between urban teachers and rural teachers is still growing larger. The per capita annual income of faculty in rural primary school and middle school is equal to only $68.8 \%$ and $69.2 \%$ respectively of the city faculties' annual salary. This sad situation about rural education in China is perhaps best captured by David Labaree in "Lives in the Margin" (Labaree, 2005).This satirical description does not only mean 'margin areas', but also because teachers in these areas get little financial and welfare support from the government. The low salary of teachers in rural areas is the main reason for the loss of excellent teachers and for the college graduates unwilling to teach in rural areas. The FNE policy is merely focusing on training teachers for rural areas, but it is silent on the benefits that rural teachers should get. Therefore, in order to make free-education graduates willing to go to the backwoods and dedicate themselves to rural education, the basic solution in front of the state is to increase investment in rural education and effectively improve the welfare of teachers in rural areas. Just as Cui advised, "central government and local government should take effective measures to increase salary and welfare level of teachers who work in rural areas, and give some special allowance to them, eliminate the income gap of teachers working in different areas" (Cui, 2012).

Apart from this strategy, government should also mind that "teachers alone cannot fix the nation's worst schools without simultaneous investments in resources, capacity building, and teachers' professional growth, not to mention changes in access to housing, health, and jobs" (Cochran-Smith, 2008).At this point, there are at least two strategies that can improve rural teachers' situation. Firstly, the state should improve teachers' economic income. The government should increase subsidies and one-time installation costs (hardship allowance) for teachers, which schools in cities and towns have been doing for some time to attract teachers with high qualifications. Government is supposed to effectively solve the problem of housing which free-education graduates are worried about. As for poorer regions, central government should increase investment in order to reduce the burden on local government. The second action would be to improve the social status of rural teachers. In addition to the meager income mentioned above, the other notable difficulty for teachers in rural areas is the low social status. The state should incorporate teachers' work in rural education into the civil service system so as to promote and attract more talented people, including university graduates born in the cities to devote into the development of rural education. To crown it all, government needs to explore multiple measures that would motivate high quality teachers to help improve education in disadvantaged areas.

\subsection{Bettering and Implementing "Recruiting and Exiting" Mechanism}

To start with, this section recommends that the FNE policy should become an incentive policy rather than an anti-poverty policy. FNE should be open to all aspiring young people and encourage them to work for rural education and teach in rural areas so that they make contributions to the development of rural education. This would help normal universities to have a chance to select high school graduates who have the teaching talent and disposition to major in education. Research shows that the majority of students apply for free teacher education program just because of job security and waived tuition. As a result, there are many students who do not yet fully understand the content of the policy but rashly choose FNE in normal universities. In a survey on the level of understanding of the policy by the first batch of tuition-free undergraduates, the undergraduates who did not understand the policy of free teacher education accounted for $33.33 \%$. The rest said they know the policy but that most of them knew it after they were admitted to study in normal universities whereas still many of them just know the name of the policy. Their answers were not complete when asked about what responsibilities and obligations tuition-free students should assume (Liu, Xie, Li \& Liu, S., 2009). In this regard, government and universities should make multi-faceted and multi-channels of publicity so that every high school graduate adequately understands the FNE policy before they apply for university education. This way, all students could be empowered to make their own informed decision about the choice of FNE. Furthermore, the 
"recruiting and exiting" policy should be flexible. Despite that the Notice of Measures for Implementing Free Normal Education at Normal Universities Affiliated with Ministry of Education (for Trial Implementation) requires that "excellent undergraduates who have the intention to teach in the future and whose major is not education can change their majors into education under the supervision of Ministry of Education and within the university's recruiting plan during their first-two-year studying"; "tuition-free normal students only have the chance to re-select their majors within the education area" ${ }^{27]}$ (Ministry of Education et al, 2010).But the flexibility does not open the door for tuition-free normal students who are unwilling to teach in rural areas to retreat from the major in education. The implication is that if there is no chance for undergraduates to exit from majors in education, there will be no chance for undergraduates who major in non-education areas to select education as their major. The situation is like this because the total number of students who can major in education in normal universities is limited and controlled by Ministry of Education. The consequence is that students, who discover that they have no interest in teaching after enrollment, are forced to study education, but those willing to be teachers have no chance to major in education. Therefore, the state should review "recruiting and exiting" mechanism as soon as possible, so that free-normal students can freely exit from free normal educational system if they are indeed not interested in rural education and teaching profession through a period of learning. This would eventually ensure that free-normal graduates are only those willing to engage in education in rural areas.

\subsection{The Education of Free-Education Undergraduates Should Be Radically Enriched}

Though the six normal universities have reformed teacher education in almost every aspect, there still exist many elements of the education for tuition-free undergraduates requiring further innovation. Firstly, more curriculum attention should be paid to ideological cognition of tuition-free students. Regardless of what makes them decide to major in education, normal universities should give more guidance to free-normal undergraduates. University teachers should help undergraduates develop the mindset that it is a ladder of success to work in rural areas; that it must be a hard struggle to be successful; and that obligations must be equivalent to the benefits one gets. Undergraduates should realize that it is a good chance to create feats to engage in educational work in rural areas. Secondly, universities should optimize the curriculum system. Teaching is a highly professional job like medical doctors' job. Hence, undergraduates do not only need to learn theoretical knowledge in relation to education but also need to practice education. Universities should reform the tradition of placing more emphasis on theoretical curriculum. Rather, they should provide better skill-training courses and offer more internship opportunities for undergraduates to "improve their teaching skills and teaching feeling"(Rong \& Liu, 2012). In addition, universities should also make undergraduates have a general understanding of rural education during the studying in order that they can teach in rural areas successfully. There are many challenges and ideas about rural education that tuition-free students need to know. For example, the status of rural education, characteristics of rural students, and educational views of rural parents and others. These issues could be enhanced through seminars, workshops, Internet and so forth. Thirdly, in order to make tuition-free students become a leader teacher in rural schools as soon as possible, the courses also should include courses in education management and leadership in addition to teaching professional development. The current programs do not adequately do that.

\subsection{There is Need for Continuous Professional Development Assistance for In-Service Graduates}

"As for improving the quality of education in rural areas, in-service training for free-normal-education graduates is more important than pre-service learning" (Rong \& Liu, 2012). Because of insufficient teaching experience, tuition-free graduates who teach in rural areas are easy to be assimilated or indoctrinated by adverse and outdated educational concepts and modes which are used in rural areas. These existing educational ideas and practices can negatively affect the development of teaching ability of the graduates. Therefore, normal universities, related research institutions and management agencies should provide continuing support to in-service graduates. First of all, novice graduates need help to turn teaching knowledge into good teaching practices. Tuition-free graduates have learned a lot of up-to-date teaching concepts at university, but they may know little about how to put them into practice. Therefore, on-the-job guidance should be provided. Normal universities could continue to guide graduates ideologically through supporting teams, learning platform, websites which include excellent instructional videos, and through latest educational theory and practice. Secondly, in order to foster graduates' practical ability after they take up teaching jobs, local management institutions should consider to regularly organize free normal students to observe teaching competition among excellent teachers, visit local outstanding schools and ask for help from excellent teachers. At the beginning of entries into teaching jobs, universities can organize graduates to participate the training of teaching skills as much as possible. In addition, local authorities should develop a large number of high-quality teaching resources such as magazines, books, CD-ROM related to teaching for graduates so that they can learn at any time. Lastly, establishing Profession Development School is also an important component for continuous professional development for in-service graduates and for all teachers in rural areas (Gao \& Chang, 2014). In summary, it is necessary to take many appropriate measures to support and help graduates improve rural education which the FNE policy seeks to achieve. 


\section{Conclusion}

This paper has attempted to critically analyze and evaluate the foundation, benchmarks and implementation of Free Normal Education (FNE) in China, which is meant to be an instrument for improving quality of education in rural areas. The paper has also demonstrated that while the spirit of the policy is very important in attempts to improve education in rural areas, support structures like reasonable salaries and general welfare of teachers are missing to motivate teachers so that they stay in rural areas and contribute to positive change in education. One of the consequences, hence, is that the number of qualified teachers is not significantly increasing in rural areas. Using different theoretical perspectives, the paper has questioned the wrong underlying assumptions which suggest that mere training and sending teachers to rural areas would necessarily promote the highly espoused quality of education. As a remedy, the paper, therefore, suggests several pertinent policy and practice improvements to be done from a holistic approach. This approach would ensure that strategies to improve education do not only focus on teacher training and recruitment, but also on the working conditions, income, welfare, and professional development support to teachers before and after they take up the noble teaching profession.

Note: ${ }^{~}$ About 6.5 Yuan equals 1 US Dollar.

\section{References}

Cao, W. Z. (2012). The Big Problem of Decrease in Ratio of Undergraduates Coming from Rural Areas. Study Times, p.A9.

Cochran-Smith, M. (2008). New Teacher Education in the United States: Directions forward. Teacher and Teaching: Theory and Practice, (4).

Cui, B. (2012). Why Free Normal Education Candidates Obtain Employment Departure Police Original Intention— from the Perspective of Social Mobility. Modern Education Management, 12.

Department of Development \& Planning Ministry of Education (2011). Educational Statistics Yearbook of China, 2010. People's Education Press.

Dong B. L. (2007). The Value Pursued by Free Normal Education. Education and Vocation, 9.

Early, P. M. (2008). Instrumentalism and Teacher Education in the United States: an Analysis of Two National Reports. Teachers and Teaching: Theory and Practice, 4.

Fan, L. L. (2005). Reform of Charging System of Higher Education for Fifty Years. Prices Monthly, 4.

Fu, Y. C., \& Yang, X. Y. (2012). Efficient strategies for Promoting the involvement of tuition-free Teacher-college students in basic education. Journal of Yunnan Normal University (Humanities and Social Sciences), 1.

Gan, L. H. (2011, March 12). Only 2\%t of the First Batch of free Normal Graduates Are Willing to Work in Rural Areas, and only $30 \%$ of Them Chose Teaching as Their Occupation. China Youth Daily, p.A3.

Gao, X. C. (2009). Analysis and Study on the Current Status of the Cultivation of Tuition-free Normal College Students. Journal of Tongren University, 6 .

Gao, Z., \& Chang, B. N. (2014). Problems and Countermeasures in the Education of Tuition-free Normal Students. Journal of National Academy of Education Administration, 7.

General Office of the State Council (2007a). Notice by the Ministry of Education and Other Related Departments on the Measures for the Implementation (Trial) of Providing Free Education for Students of Normal Universities Directly Under the Ministry of Education. The State Council Bulletin of the People's Republic of China, 17.

General Office of the State Council (2007b). The Notice of Measures for Implementing Free Normal Education at Normal Universities Affiliated with Ministry of Education (for Trial Implementation). http://www.gov.cn/zwgk/2007-05/14/content_614039.htm

Hallinan, M. T., \& Khmelkov, V. T. (2001). Recent Developments in Teacher Education. Journal of Education for Teaching, 2. http://dx.doi.org/10.1080/02607470120067918

Jiang, X. J. (2007). Ten Thousands of Students Enrolling in Free Normal Education, nearly $90.8 \%$ of Them Are from the Middle and West. China Education Daily, p.A2.

Labaree, D. (2005). Life on the margins. Journal of Teacher Education, 56(3). http://dx.doi.org/10.1177/0022487105275916

Li, C. L. (2010). Expansion of Higher Education and Inequality in Opportunity of Education: A study on effect of"Kuozhao" Policy on Equalization of Educational Attainment. Sociological Studies, (3). 
Li, X. J., \& Sun, C. H. (2011). An Investigation on Study of Tuition-free Normal Students. Contemporary Educational Science, (7).

Liu, Z. X., \& Dang, B. T. (2007). A New Spring of Normal Education: an Interview with the Communist's Party Secretary of Central China Normal University, Ding Lieyun and the President Ma Min. Education and Vocation, (10).

Liu, X., Xie, C. K., Li, J. H., \& Liu, S. Q. (2009). Research on Problems and Countermeasures in Implementing Policy of Free Normal Education. Modern Education Science, (6).

Ministry of Education (2008, December 5). National Report of Education Inspection 2008 (Summery), China Education Newspaper, p.A2.

Ministry of Education et al (2010).Measures for Placement of Employment of Free-Normal-Education Graduates Studied in Normal Universities Affiliated with Ministry of Education. http://www.edu.cn/jyzl_zhzl_8561/20100527/t20100527_479297.shtml.

Ministry of Education (2010). Measures for Placement of Employment of Free-Normal-Education Graduates Studied in Normal Universities Affiliated with Ministry of Education. http://www.edu.cn/jyzl_zhzl_8561/20100527/t20100527_479297.shtml.

National Bureau of Statistics of China (2011). Communique of Major Figures on the 2010 Population Census (No.1), People's Daily, p.A9.

Rong, Z. K., \& Liu, H. (2012). Suggestions for Free Normal Education Policy and its Implementation: A comparison between Policy of Free Normal Education and that of Nationa. Research in Education Development, (18).

Sun, D. H. (2010). Reflection and Prospects on Implementation of Policy of Free Normal Education. New Curriculum Research, (3).

Tian, D. D. (2011). Teaching in Cities, How Can Rural Education Really Be "Touched"? . People's Daily. p.A12.

Wang, S. B. (2011). Study on Policy of Free Normal Education from the Perspective of Education Equilibrium. Adult Education, (8).

Wen, J. B. (2011b). Rural Education Must Be Done More Properly. People's Daily, p.A2.

Wen J. B. (2011a). Running Rural Schools Well, and Improving Treatment of Rural Teachers. Young Teachers, (1).

Wen J. B. (2011c). Accomplishing Sacred Mission of Imparting Knowledge and Educating Students. People's Daily, p.A3.

Wen, J. B. (2007, March 18). Government Work Report: On The fifth Session of the Tenth National People's Congress on March $5^{\text {th }}$. People's Daily, p.A1.

Wu, Q. Q. (2011). Where Did Batch of Tuition-free Normal Graduates Go?. People's Daily, p.A20.

Net, X. H. (2006). Wen Jiabao Hosted Forum about Educational Working Four Times Successively in Zhongnanhai. http://news.xinhuanet.com/politics/2006-11/22/content_5360313.htm.

Yue, C. J. (2012). Problems of Employment Structure of University Graduates in Ladder-type Labor Market and Its Countermeasures in China. China Higher Education, (6).

Zhou, Q. (2010). Reflection on Balanced Development of Rural Education. Journal of Fujian Provincial Committee Party School of CPC, (12).

\section{(c) B B}

This work is licensed under a Creative Commons Attribution 3.0 License. 